\title{
A different approach to teaching French as a foreign language at preparatory school: From curriculum development to practice
}

\author{
Ayşe Işık Akdağ \\ istanbul University, School of Foreign Languages
}

\begin{abstract}
:
This study aims to evaluate the effects resulted from the implementation of a new curriculum for the teaching of French as a foreign language (FFL) at undergraduate level. Since majority of students found foreign language coursebooks (FLCS) not motivating, a curriculum that aims to develop language competences by excluding FLCs was designed. The theoretical framework of this curriculum is based on the Common European Framework of Reference for Languages, on the Bologna Process and on the National Qualifications Framework for Higher Education. The research was designed as an action research in education. The sample consisted of 30 prep class students at a state university. The data collected from the students through a questionnaire were analyzed by SPSS Statistics 21. The results of the study indicate that students found this new curriculum very successful. Except one course, satisfaction levels of $100 \%, 92 \%, 82.6, \% 6.4$ and 54.2 were achieved for Book Reading, Verbal Communication, Grammar, Dictation and Written Communication. The designed curriculum may be used in different institutions if altered in line with learners' needs.
\end{abstract}

Keywords: language learning curriculum development; teaching of French as a foreign language; CEFR; higher education

\section{İnönü University}

Journal of the Faculty of Education Vol 19 No 3, 2018

pp. 231-239

DOI: $10.17679 /$ inuefd.331092

Received : 27.07.2017

Accepted : 07.11.2018

\section{Suggested Citation}

Akdağ, A.I. (2018). A different approach to teaching French as a foreign language at preparatory school: From curriculum development to practice, Inonu University Journal of the Faculty of Education, 19(3), 231-239. DOI: 10.17679/inuefd.331092 


\section{INTRODUCTION}

The aim of this study is to evaluate the efficiency of a new curriculum for the teaching of French as a foreign language (abbreviated as FFL in English and as FLE in French) from students' point of view. It is a classroom based action research implemented in prep classes of a state university. One may wonder why we thought about a new curriculum without the use of a foreign language coursebook (FLC henceforth), since when foreign language teaching is concerned, almost all stakeholders of education from primary education to university would think of learning a foreign language with FLCs. Indeed, when one analyses the catalogues of outstanding publishers of FLCs such as Hachette, Didier FLE, Clé International, s/he will observe that they offer a large variety of options to students of any age group. Undoubtedly, using FLCs facilitates educational activities, helps the instructor in educational planning processes, provides guidance while organizing in-class activities and ensures course materials to be at a level in compliance with the Common European Framework of Reference for Languages (CEFR).

However, it has some insufficiencies that lead us to find out a new way of French teaching: First of all, based on our interviews ${ }^{1}$, majority of our students find FLCs boring: At the end of each academic year, in order to improve quality, we ask our students through interviews to comment on their learning process. In these interviews, we encourage them to comment on positive and negative factors that affected their learning and ask their opinion about courses. Although we used different FLCs, students kept saying that they found none of the FLCs interesting. Especially they mentioned that texts in the FLC were long.

Our interview results are similar to O'Sullivan's (1990:135) survey results in his doctoral thesis. In his survey conducted among foreign language students, majority of learners (75.6\%) thinks that texts in FLCs are "sometimes interesting", $13.3 \%$ boring vs. $10.9 \%$ very interesting. O'Sullivan states that "whereas the initial impact of the coursebook is such as to generate motivation, it may flag somewhat in the crucial area of sustaining it" (1990:135).

Secondly, despite the fact that there are numerous FLCs available at the market with regard to different target audience and field of specialization, foreign language learning is still restricted to general aims. In other words, when a FLC is picked for up from the adults category, this very book may be used in a language school, a university class or with a student group who wants to learn French for some other raisons but these 3 learning situations are different from each other and the same book cannot meet the requirements of all. Gray (2000) points out this issue with a broader perspective: According to the researcher, coursebooks are written by "one size fits all" point of view disregarding the locality, and the content is not always compliant with today's student needs.

Other researchers also point out some insufficiencies of coursebook use in the classroom: Edge \& Wharton (1998) and Apple \& Jungck (1990) find textbooks as a "de-skilling" instrument which causes the diminution of cognitive and pedagogical skills of teachers. A similar criticism comes from Littlejohn (1992:84) who states that coursebooks "reduce the teachers' role to one of managing or overseeing preplanned events". Crawford (2002) summarizes several shortcomings of textbooks among which we can enumerate some as inappropriate language use, lack of discourse competence and equity in gender representation, inadequate cultural components, and problems with the contextualization of language activities.

As a result of the above mentioned deficiencies, we decided to eliminate FLCs from our education and did research about how to teach without a coursebook. Surprisingly, we did not find any study tackling the issue of French teaching as a foreign language without a FLC. Although there are many articles or books about curriculum design, teaching methods, evaluation of coursebooks, no empirical study dealt with FLE without the help of FLCs. Therefore our study seeks to fill this research gap in the field.

\footnotetext{
${ }^{1}$ The interviews mentioned are realized in the French lecturers' room after the final exam of the academic year. Each year, students were asked to comment on/grade the proficiency of the FLC used as; low, average and successful.

a. In 2012, of 15 participant students 9 reported that they found it boring, 4 said that the LC was neither boring nor interesting, 2 found it interesting.

b. In 2016, another group of students were asked how much they agreed to this statement: "I prefer language competence based courses to coursebook used courses". Of 37 students 12 said that they strongly agreed, 9 agreed versus 3 totally disagreed and 3 disagreed.

c. In 2017, 21 students were asked the grade the efficiency of FLC and how much the FLC motivated them. 9 found the FLC non efficient versus 6 who found it average and 6 good. For the motivation, 9 stated that the FLC did not motivate them whereas 5 found it motivating, 6 stayed neutral.
} 
The research questions that guided the study are:

1. Can we improve the quality of French teaching by eliminating FLCs?

2. How can such a curriculum be designed?

3. Would this new curriculum satisfy students' needs?

The importance of the study is that it proposes a new curriculum that takes account of localness of learning by combining Qualifications Framework for Higher Education (QFHE) with speech acts. Thus, instead of imposing a single type of teaching, the curriculum contains the planning of the learning process, while providing the freedom to the instructor to act in accordance with the specific requirements of student groups; hence it can be applied in all preparatory classes and to different levels. Owing to the curriculum designed, it is aimed to render education processes more holistic at preparatory classes at undergraduate level, to increase students' attentiveness to the class, to link localness of learning with global demands and to improve the quality of French teaching.

The article presents at the first place, the new curriculum, how it is formed and what theoretical implications are considered both from the language teaching and curriculum studies perspective. And then we move on to its evaluation from the student's point of view by analyzing their responses through the statistics program SPSS to a questionnaire administered at the end of the academic year.

\section{Literature review}

When FLCs are eliminated from education, educational planning requires a great deal of attention. A highquality output can be achieved only through high-quality planning and a practice pertinent to such planning. In order to achieve a high-quality output the theoretical background of the curriculum, at international level, was based on the Bologna Process criteria, Qualifications Framework for European Higher Education Area (QF-EHEA) and at national level, on QFHE. In particular, for the teaching of French, CEFR was used as the basis.

\section{Bologna Process and QFHE}

The main objective of the Bologna Process is to improve transparency, recognition and quality by drawing up comparable programs in higher education but integration in education should not be considered as presenting exactly the same programs in higher education institutions. The Process lays down the minimum qualifications to be acquired for a specific area, but does not rule out the originality of universities. In our country, the Council of Higher Education (CoHE) is responsible for implementing the Bologna Process. Pursuant to the establishment of the Working Group on the Qualifications in Higher Education by CoHE, national qualifications were associated with QF-EHEA, and the QFHE was established. In order to specify the qualifications, the Working Group took the main fields specified by the International Standard Classification of Education (ISCED97) as the basis (Erdoğan, 2010:22-27).

Students who are enrolled in French Prep School in our university will continue their academic programs at the Department of French Teaching or the Department of French Language and Literature. Within the main fields listed in the QFHE, these departments are categorized under Social Sciences no. 22. For Social Sciences at undergraduate level, academic qualifications specified in the QFHE are investigated under 3 sections, i.e. Knowledge, Skills and Competences. In order to distinguish these concepts, the Bologna guideline prepared by CoHE gives the following definitions: While Knowledge implies "the internalization of data through learning"; Skills imply "the ability to implement knowledge, to solve problems and to complete tasks". Competence, in turn, indicates "the capability to utilize knowledge as well as personal, social and/or methodological skills in work environment and in professional and personal development" (Erdoğan, 2010:19; 64-65). We planned the new curriculum in these 3 sections so that it would be in accordance with QFHE.

\section{Common European Framework}

Foreign language teaching in Europe is carried out in accordance with common policies set out by the Council of Europe (CE). With the introduction of CEFR, these policies have been transformed into a resource from which instructors and students may benefit. CEFR specifies necessary competences for language learning. As an example, "Linguistic competences include lexical, phonological, syntactical knowledge and skills and other dimensions of language as system" while sociolinguistic competences are related with the social aspect of language. Pragmatic competences focus on function, role of context in the construction of meaning, coherence and cohesion of discourse and speech acts (CE, 2001:13-14). In the CEFR, there are 3 broad reference levels of proficiency as A, B and C, each of which is divided into two sub-levels. In each reference level, what students can do is specified for listening, reading, spoken interaction, spoken production and writing. 
CEFR identifies students as social agents who fulfill a certain task under a specific situation and condition ( $C E$, 2001:9). During a course, in order to accomplish the demanded task, students have to communicate. The communication is carried out successfully only if the student correctly analyses the social status of the listener, the communication context and the linguistic material he or she will employ in accordance with his or her intension, and this requires the utilization of appropriate speech acts for the communication context.

\section{Curriculum Design}

Several researchers tried to define curriculum in different ways (Jenkins \& Shipman, 1977; Johnson, 1967; Kerr \& Berman, 1969; Neagley \& Evans, 1967; Pratt, 1980; Stenhouse, 1975). For Barrow (1984) curriculum is "a programme of activities (by teachers and pupils) designed so that pupils will attain as far as possible certain educational ends or objectives" while for Richards (2013:6) it is "the overall plan or design for a course and how the content for a course is transformed into a blueprint for teaching and learning which enables the desired learning outcomes to be achieved". Nunan (1998:1) defines it "in terms of what teachers actually do; that is, in terms of 'what is', rather than "what should be"." Within the scope of this study, as Nunan described, curriculum was dealt with a descriptive rather than a prescriptive approach.

Richards (2013:8-28) examines 3 different approaches to curriculum design and names them as forward, central and backward design. The main difference of these approaches is that they deal with input, process and output in different orders. The curriculum approach employed in this study is the backward design. The backward design starts with the investigation of desired results or outcomes (in our case CEFR qualifications). The content and the process are developed from the target behaviors. This approach does not prescribe any specific educational method or philosophy. Various teaching strategies can be employed in order to achieve the desired objective, yet the educational method/activities are selected after the target behaviors are specified (Richards, 2013:22).

Task-based instruction and competency-based instruction (CBI) are commonly used within the framework of this approach. In our curriculum, CBI model was used because as Richards (2005:42) points out "what characterizes a competency-based approach is the focus on the outcomes of learning as the driving force of teaching and the curriculum". As mentioned above, CEFR established the qualifications to be acquired in compliance with language competences for all language levels. In other words, it facilitated the task to design the stages required by a curriculum to be drawn up based on the backward design. The stages pursued in the curriculum were as follows: identify the language competences to be acquired by students, specify the target behaviors for each language competence and specify the content, and specify the educational material and activities.

The backward design also starts with needs analysis. Richards (2001:90) defines the goal of need analysis as "to collect information that can be used to develop a profile of the language needs of a group of learners in order to be able to make decisions about the goals and content of a language course". In this study, needs were specified following the democratic approach, i.e. the demands and concerns of students as well as the opinions of the instructors were received and the curriculum was designed accordingly.

In the preparation of the new curriculum, among the teaching approaches, the learner-centered approach was pursued as it enables the curriculum to be designed on the basis of students' needs (Pegem, 2008:64). Hence, the student participates in the course actively and learns with respect to the language teaching method of the professor, either by writing or fulfilling the task etc. The instructor eludes the role of authority giving information and assumes a participatory role regulating the learning process. Such properties of the learner-centered approach are also among the elements highlighted by current language learning methods. The curriculum was initially prepared for the basic levels of CEFR, i.e. A1 and A2. Linguistic development was not the only target pursued in the curriculum design, but rather it was decided to include the culture and literary life, social and historical development of the foreign language into the education process. Thereby, apart from reading, writing, listening and speaking classes in which language competences were developed, courses which complemented these were also included in the curriculum. For instance, in view of the fact that these students would teach French or analyze French texts in the forthcoming years of their education, Grammar courses were included in the curriculum. Furthermore, a Creative Activity (CrA) class was also introduced so as to enable the students to put what they had learned into practice through drama and to enjoy the learning process. In order to obviate spelling errors and to raise awareness on the differences that minor variations in spelling may create in meaning, it was considered appropriate to introduce a course on Dictation. Hence, the courses were planned as follows: Grammar, Written Communication (Reading Comprehension and Writing), Verbal Communication (Listening Comprehension and Speaking), Book Reading (BkReading), CrA and Dictation. It was decided to reinforce students' vocabulary knowledge through activities and assignments given in these classes. 
However, there is one caveat in this planning: how would each course be linked to another? A curriculum based on cyclical planning in language learning, and on speech acts was envisaged. (See Billières (2015) for the speech acts in FFL) Especially, common speech acts were specified for all courses in a given week, and each course was organized accordingly. The speech acts were identified on the basis of CEFR. For example, for the week when "speaking about daily routines" speech act would be addressed for the A1 level of CEFR, the courses were planned as follows:

In the Grammar class, students would learn pronominal verbs employed in daily activities. As vocabulary, teaching how to tell the time and expressing various activities performed routinely in a day (waking up, combing hairs etc.) were envisaged. In the reading comprehension section of the Written Communication class (WrCom), texts on these activities would be read. Similarly, in the listening comprehension section of the Verbal Communication (VCom) class, audio materials on telling the time and daily routines would be listened. In writing and speaking, the student would write or tell what $s /$ he or anybody else does in a day. In $\mathrm{CrA}$, they would strengthen what they have learned through drama. They would also read theatre scripts of French literature and get engaged in activities such as playing these texts and learning concepts of the French culture. In the BkReading class, a whole pre-specified book would be read together with the students.

Speech acts were designated for all weeks of the academic calendar in line with this plan, and courses were planned accordingly. The sample curriculum for the abovementioned week is as follows:

Table1

The new curriculum

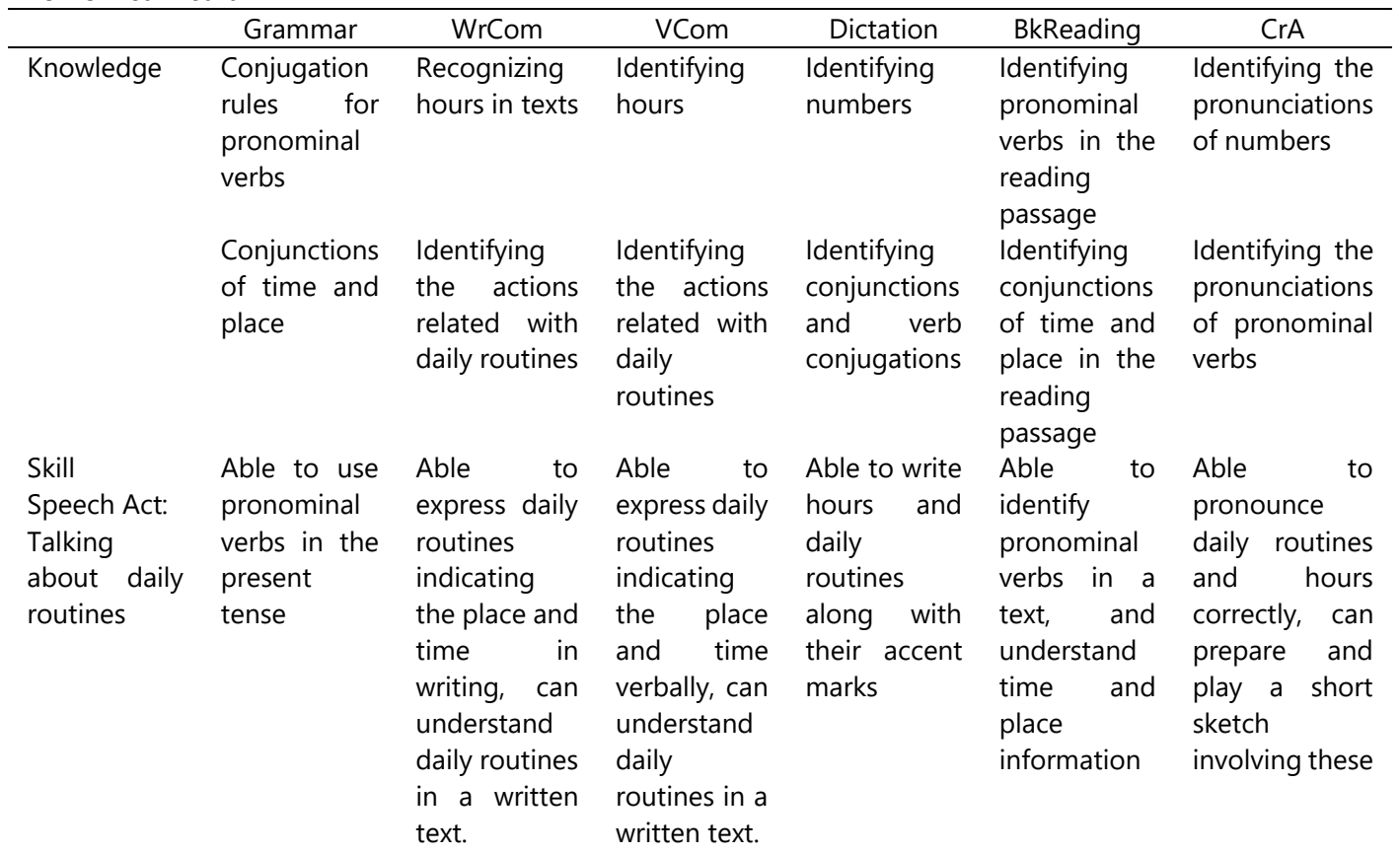

CEFR Qualifications

Can understand the questions and instructions, and follow simple and short guidelines

Can understand numbers, prices and hours

Can write simple short notes and messages on daily life.

As the table shows, each speech act, knowledge and skill concerning CEFR qualifications were stated separately for each course in the curriculum. Thereby, the curriculum was planned in accordance with CEFR, QFHE and the Bologna Process. Vocabulary was not specified in the curriculum as the instructor teaches the vocabulary $s /$ he deems proper within the scope of each course. Hence, students can enrich their lexical knowledge not only on a single theme, but on a multiplicity of themes. For instance, in an activity of the listening class which was about the opening and closing hours of institutions in France, students also learned the names of the places visited on a daily basis (hospital, super market, post office etc.). Similarly, in a text employed in the WrCom class about which television show was watched while performing certain daily routines, students learned the vocabulary on television (turning the TV on and off, program types such as documentaries, quiz shows etc.). 


\section{METHOD}

The aim of the study is to evaluate the efficiency of a new curriculum for FFL from student's point of view. Thus, research is based on action research which allowed us to plan, implement and evaluate the proposed curriculum. In the framework of education, action research is a research type employed to improve the quality of educational practices and is carried out in solution-oriented cooperation (Aksoy, 2003:477; Beyhan, 2013:71). According to Ferrance (2000:26) "action research is used for various purposes: school-based curriculum development, professional development, systems planning, school restructuring, and as an evaluative tool". In this study a solution was proposed to improve the quality of French teaching and was implemented by the researcher along with other instructors at the department. Therefore, the action research conducted in the study focused on a specific school for curriculum development and was used to "chart the effects of implementation of a curriculum" (Ferrance, 2000:27).

The steps that were employed in our study were as follows: Plan-Implement-Reflect. The Planning stage was oriented to curriculum planning. During the Implementation step, the planned curriculum was put into practice, and data were collected by various means. These data were examined during the Reflection step.

\section{Study Group}

The curriculum drawn up within the context of the research was applied in French Prep School of İstanbul University during the fall and spring term. The sample of the research consisted of 30 Turkish students of French Prep School who attended preparatory language courses regularly therefore who received 25 hours of French teaching per week, which makes 700 hours of French language course totally. (350 each term) Participant students were 18 and older and had no experience of FFL before. They were to continue their education after preparatory class at the undergraduate programs of French Language and Literature Department or the Department of French Teaching.

\section{Data collection tools}

Data about the implementation of the new curriculum were collected from students through a questionnaire consisting of 30 questions. Among the various question types which can be employed in a questionnaire, gradation and interpretation questions were selected. The students were asked to grade their opinions on the following points for each course as $A, B$ or $C$ :

- The contributions/efficiency of the course

- The proficiency of the material used during class hours

- Whether the instructor could manage to motivate them or not

Also, there is a second part (an interpretation question) in which students may write their opinions, comments or suggestions about the implementation of the new curriculum. The questionnaire was conducted face-toface with the students at the end of the spring term, in other words when students completed 700 hours of French teaching. Questions and purpose of the questionnaire were explained to them. Students are encouraged to reflect their learning process as honestly as possible by means of questions.

\section{Data analysis}

In this classroom based action research quantitative data were obtained from the questionnaire in which students evaluated the new curriculum. 30 students filled in the survey conducted at the end of the academic year. The reliability of the instrument was calculated by the use of SPSS Statistics 21, and the Cronbach's $\alpha$ value was found .84. Although the number of the sample was restricted, normality was achieved with the $p$ value of Shapiro Wilk Test .72.

\section{FINDINGS}

Our analysis started with the question in reply of which students graded the course efficiency. Table 2 shows students' opinions on course efficiency and Table 3 gives descriptive information about the efficiency of courses. 
Table 2

Students' opinions on course efficiency

\begin{tabular}{lcccccccccccc} 
& \multicolumn{2}{c}{ Grammar } & \multicolumn{2}{c}{ VCom } & \multicolumn{3}{c}{ Dictation } & \multicolumn{3}{c}{ BkReading } & \multicolumn{3}{c}{ CrA } & \multicolumn{2}{c}{ WrCom } \\
Efficiency & $\mathrm{f}$ & $\mathrm{p}$ & $\mathrm{f}$ & $\%$ & $\mathrm{f}$ & $\%$ & $\mathrm{f}$ & $\%$ & $\mathrm{f}$ & $\%$ & $\mathrm{f}$ & $\%$ \\
\hline Low & 0 & 0 & 0 & 0 & 4 & 15.4 & 0 & 0 & 19 & 76.0 & 2 & 8.3 \\
Average & 4 & 17.4 & 2 & 8 & 5 & 19.2 & 0 & 0 & 2 & 8.0 & 9 & 37.5 \\
Successful & 19 & 82.6 & 23 & 92 & 17 & 65.4 & 27 & 100 & 4 & 16.0 & 13 & 54.2 \\
TOTAL & 23 & 100 & 25 & 100 & 26 & 100 & 27 & 100 & 25 & 100 & 24 & 100 \\
\hline
\end{tabular}

Data analysis revealed that 3 students expressed their opinions in a paragraph form and did not grade any course. The answers given by these students were not included in the statistical analysis. Another group of students, on the other hand, evaluated only a few courses and left the rest blank. The findings of the data analysis indicated that students had a positive attitude towards the new curriculum. The survey results on the efficiency of the courses in the implementation showed that most of the courses were carried out successfully. Success levels of $100 \%, 92 \%$ and $82.6 \%$ were achieved respectively in BkReading, VCom and Grammar courses. However, efficiency average was 1.4 out of 3 for $\mathrm{CrA}$.

Table 3

Descriptives for the efficiency of courses

\begin{tabular}{lcccccc} 
& Grammar & VCom & Dictation & BkReading & CrA & WrCom \\
\cline { 2 - 5 } Mean & 2.82 & 2.92 & 2.5 & 3 & 1.4 & 2.45 \\
Median & 3 & 3 & 3 & 3 & 1 & 3 \\
\hline
\end{tabular}

Courses which had a mean above 2 (out of 3) and which were rated 'successful' by the majority of the students were considered efficient. In this context, it could be said that all the courses were efficient except $\mathrm{CrA}$ which was found inefficient by $76 \%$ of the students. The failure might be due to the material employed (i.e drama) and/or various other reasons. In order to determine if the reason of failure in this course was the choice of the drama, the responses to the $2^{\text {nd }}$ question of the questionnaire were examined. This question asked the students to grade the proficiency of the material employed. As indicated by Table 4, it was found that majority of the students marked the proficiency of the drama 'low' while the number of those who found it 'average' or 'successful' was the same.

Table 4

Drama Proficiency

\begin{tabular}{lccc}
\hline & $f$ & Valid\% & Cumulative\% \\
\cline { 2 - 4 } Low & 19 & 70.4 & 70.4 \\
Average & 4 & 14.8 & 85.2 \\
Successful & 4 & 14.8 & 100,0 \\
Total & 27 & 100.0 & \\
\hline
\end{tabular}

The results indicated that students were not satisfied with the drama performed in the course. In this case, it might be possible to establish a connection between the low efficiency of the course and low proficiency of the drama.

Beside the gradation questions, interpretation questions of the questionnaire are also examined. In the part where they wrote their opinions, $13.3 \%$ of the students stated for CrA that they did not want to take a role in the play because it did not motivate them and therefore, they were not as active as others in the classroom. Also they suggested that this course be optional. One student said: "In the first year of prep school, I think that drama is no use at all". Another student stated: "The language of the drama concerned was above our level".

The survey results were evaluated during the interview with instructors. The instructors said that they were satisfied with the play staged as a result of the activities performed in the $\mathrm{CrA}$, but they admitted that further arrangements were necessary about the course in view of the students' opinions. They did not mention any problem concerning the other courses. On the contrary, all stated that they were satisfied with the new curriculum.

Research findings showed that students found all the courses in the new curriculum successful except for one course- $\mathrm{CrA}$ the failure of which might be considered because of the mischoice of the drama. Based on survey results, a strategic action plan for the next year was designed. Since Grammar, VCom, WrCom and 
Dictation had highly rated scores, no change was foreseen for these courses. For the $\mathrm{CrA}$, on the other hand, the need for improvement arose: A play that students could understand more easily and hence could be motivated better was selected. Moreover, taking into consideration students' point of view, it was decided to offer the $\mathrm{CrA}$ as an elective course so that the students' participation might be on a voluntary basis.

\section{DISCUSSION \& CONCLUSION}

This study based on action research, presented a new sample curriculum for prep schools where French is taught as a foreign language. Designing a curriculum requires various fields of education to be taken into consideration. In this respect, the theoretical background of the proposed curriculum was based on CEFR and speech acts in terms of foreign language teaching, on learner-centered approach in terms of educational sciences, on backward design in terms of curriculum design, and on QFHE set out by CoHE and the Bologna Process in terms of higher education policies.

The designed curriculum as such was tested by means of action research. The action research employed in the study was oriented towards program development. Data were collected through a questionnaire from the students in the research. The findings obtained as a result of data analysis revealed the efficiency of the curriculum from the students' points of view except for the CrA course that would be offered as an elective for the following year. The feedbacks received from students indicated that competency-oriented and speech act based instruction had mostly a positive impact on their learning processes.

In French prep schools, teaching based on language competences and speech acts has various positive aspects compared to education based on the use of FLCs. In the first place, because the new curriculum is designed after the needs analysis, it tries to link the localness of learning with global expectations, and offers a 'made to order' solution to its intended audience (see Gray, 2000).

In the second place, far from being a de-skilling instrument (see Edge \& Whorton, 1998; Apple \& Jungck, 1990), it allows teachers to design their course as they wish (of course respecting the speech act of the week), thus, encourages teachers' creativity. Instead of reducing teachers' roles, it provides them a learning environment where they can reach to their utmost potential. In contrast to teaching with a FLC, the instructor is not restricted with the text, audio material etc. given in the FLC. S/he may use any activity s/he wants in the class, which may in turn improve the motivation of the teacher and the students.

In the third place, as the FLC introduces a subject in a specific context, students see only a single context for a specific speech act in FLC use. However, since a specific speech act is studied in different competenceoriented courses in this practice, students can reinforce what they have learned in various contexts. Utilizing the same speech act in different contexts, they can also improve their lexical and pragmatic competences. Moreover, $\mathrm{CBI}$ in the new curriculum is the latest and newest language approach (Richards \& Rodgers, 2014; Auerbach, 1986). Mendenhall (2012) points out that CBI can improve the quality and consistency while Auerbach shows its beneficial effects on students' learning. Richards (2005) states that the CBI allows to focus on special learning needs of the students. Findings obtained in this study support researchers' point of view by exposing high success rates of the course efficiency after the implementation of the new curriculum.

$\mathrm{CBI}$ can also be observed in the first year of undergraduate education in our country. For example, Verbal Communication, Reading and Written Communication courses are available at the curricula of French Teaching departments. However, the classification in the curriculum presented here and that in undergraduate programs are rather different. Courses in undergraduate programs are designed separately. A student may fail Reading 1, yet pass Reading 2 or Writing 1. There is no (or little) direct connection between the contents of these courses except their levels. In the curriculum offered for French Prep School, on the other hand, all language competences are connected with each other through the utilization of the same speech acts. Every week, effort is made to introduce the relevant CERF qualification through related speech acts for each language competence.

As a result, this research shows that we are not bound to FLCs in FLE, and presents a curriculum with which students are satisfied. This sample curriculum presented for French teaching is designed for prep schools at university, but may give successful results within the body of other educational institutions if altered in accordance with the new students' profile.

\section{REFERENCES}

Aksoy, N. (2003). Eylem Araştırması: eğitimsel uygulamaları iyileştirme ve değiştirmede kullanılacak bir yöntem [Action research: a method to be used for the improvement and change in educational applications]. Educational Administration: Theory and Practice 9, no.4: 474-489. Retrieved from http://www.kuey.net/index.php/kuey/index. 
Auerbach, E.R. (1986). Competency-based ESL: one step forward or two steps back? TESOL Quarterly 20, no.3: 411-429.

Apple, M. W., \& Jungck, S. (1990). "You Don't Have to Be a Teacher to Teach This Unit:" Teaching, Technology, and Gender in the Classroom. American Educational Research Journal, 27(2), 227-251.

Barrow, R. (1984). Giving Teaching Back to the Teachers. A Critical Introduction to Curriculum Theory. Brighton: Wheatsheaf Books.

Beyhan, A. (2013). Eğitim örgütlerinde eylem araştırması [Action research in educational organizations]. Journal of Computer and Education Research 2:65-89. Retrieved from http://www.joucer.com.

Billières, M. (2015). Actes de language et enseignement du FLE [Speech acts and teaching French as a foreign language] [Web log post]. Retrieved from http://www.verbotonale-phonetique.com/actes-delangage-enseignement-fle

CE-Council of Europe. (2001). Common European Framework of Reference for Languages: Learning, teaching, assessment. Strasbourg: Press Syndicate of the University of Cambridge.

Crawford, J. (2002). The Role of materials in the language classroom: Finding the balance. In Methodology in language teaching: An anthology of current practice, ed. J. C. Richards and W. A. Renandya, 80-93. USA: Cambridge University Press.

Edge, J., \& Wharton, S. (1998). 13. Autonomy and development: living in the materials world. Materials development in language teaching.Elliot, J. (1991). Action research for Educational Change. Philadelphia: Open University Press.

Erdoğan, A. (Eds). (2010). Yükseköğretimde yeniden yapılanma: 66 soruda Bologna süreci uygulamaları [Restructuring in higher education: Bologna process in 66 questions]. Ankara: YÖK.

Ferrance, E. (2000). Action research: themes in education. USA: Northeast and Islands Regional Educational Laboratory at Brown University.

Gray, J. (2000). The ELT coursebook as cultural artefact: How teachers censor and adapt.ELT Journal 54(3), 274-283.

Jenkins, D., Shipman, M. D., Sockett, H., Macdonald, B., Walker, R., \& Hamilton, D. (1977). Curriculum: an introduction. London: Open Books.

Johnson, M. (1967). Definitions and models in curriculum theory. Educational Theory 17:127-40.

Kerr, J. F., \& Berman, L. M. (1969). Changing the curriculum. British Journal of Educational Studies 17 (2):223-224.

Littlejohn, A.L. (1992). Why are ELT materials the way they are? (Unpublished doctoral dissertation). Lancaster University, United Kingdom.

Mendenhall, R. (2012). What is competency based education? Huffington Post. Retrieved from http://www.huffingtonpost.com/dr-robert-mendenhall/competency-based-learningb_1855374.html.

Neagley, R. L., \& Evans, N. D. (1967). Handbook for effective curriculum development. Prentice Hall.

Nunan, D. (1998). The learner-centred curriculum: a study in second language teaching. Cambridge/ New York/ Melbourne: Cambridge University Press.

O'Sullivan, A. V. (1990). The foreign language coursebook: a study of its role in learner motivation (Doctoral dissertation, Institute of Education, University of London).

Pegem. (2008). Öğretmen adayları için Kpss eğitim bilimleri eğitim bilimine giriş, program geliştirme sınıf yönetimi [Introduction to educational sciences, curriculum development, class management for teacher trainees in the framework of public personnel selection examination]. Ankara: Pegem Yayınevi.

Pratt, D. (1980). Curriculum design and development. New York: Harcourt Brace Jovanovich.

Richards, J.C. (2001). Curriculum development in language teaching. Cambridge, UK: Cambridge University Press.

Richards, J. C. (2005). Communicative language teaching today. SEAMEO Regional Language Centre.

Richards, J.C. (2013). Curriculum approaches in language teaching: Forward, Central, and Backward Design. RELC Journal 44, no.1:5-33.

Richards, J. C., \& Rodgers, T. S. (2014). Approaches and methods in language teaching. Cambridge university press.

Stenhouse, L. (1975). Defining the curriculum problem. Cambridge Journal of Education 5, no.2:104-108.

İletişim/Correspondence

Öğ. Gör. Dr. Ayşe Işık AKDAĞ aysea@istanbul.edu.tr 